$\mathcal{H a l}: 8-12$

\title{
BIODIVERSITAS IKAN MIRIK (Mastacembelus spp) DI SUNGAI NAHULA LABUHAN BATU SELATAN
}

\section{BIODIVERSITY OF SPINY EEL (Mastacembelus spp) IN THE RIVER NAHULA OF SOUTH LABUHAN BATU}

\author{
RIJES SIREGAR ${ }^{1}$ ), KHAIRUL ${ }^{12^{*}}$ ), ROSMIDAH HASIBUAN ${ }^{3}$ ) \\ ${ }^{1,23}$ ) STKIP LABUHAN BATU, JI. SM Raja No.126-A KM 3,5 Aek Tapa, Rantauprapat \\ *Email : khairulbiologi75@gmail.com
}

\begin{abstract}
Abstrak. Tujuan penelitian ini adalah untuk mengetahui Indeks Keanekaragaman, Indeks keseragaman, Indeks Similaritas dan Indeks Dominansi Ikan Mirik Di Sungai Nahula. Penelitin ini merupakan penelitian eksploratif dan metode penentuan stasiun pengamatan dengan purposive sampling, yakni berdasarkan tingkat kedalaman perairan sungai. Pengambilan sampel ikan menggunakan pancing dan electrical fishing. Data lapangan yang dikumpulkan selanjutnya dianalisis menggunakan program Mikrosoft Excel. Hasil penelitian menunjukan Indeks Keanekaraman ikan pada stasiun $1(0)$, stasiun $2(0,15)$, dan stasiun $3(0)$. Indeks Keseragaman diperoleh pada stasiun 1 (0), stasiun $2(0,22)$, dan stasiun $3(0)$. Indeks Similaritas diperoleh pada stasiun 1 dan $2(66 \%)$, stasiun 2 dan $3(66 \%)$, dan stasiun 3 dan 1 (100\%). Indeks Dominansi diperoleh pada stasiun $1(0,16)$, stasiun $2(0,08)$, dan stasiun $3(0,02)$.
\end{abstract}

\section{Keywords : Mastacembelus spp, biodiversitas, sungai nahula}

\begin{abstract}
The purpose of this study was to determine the Diversity Index, Uniformity Index, Similarity Index and Dominance Index of spiny eel on the Nahula River. This research is an exploratory study and the method of determining the observation station with purposive sampling, which is based on the depth of the river. Fish sampling using fishing rods and electrical fishing. The field data collected was then analyzed using the Microsoft Excel program. The results showed fish diversity index at stations 1 (0), station $2(0.15)$, and station $3(0)$. The Uniformity Index is obtained at station $1(0)$, station $2(0.22)$, and station $3(0)$. Similarity index was obtained at stations 1 and $2(66 \%)$, stations 2 and $3(66 \%)$, and stations 3 and 1 (100\%). The dominance index was obtained at station $1(0.16)$, station $2(0.08)$, and station 3 (0.02).
\end{abstract}

Keywords : Mastacembelus spp, biodiversity, nahula river

\section{Pendahuluan}

Sungai Nahula merupakan salah satu anak Sungai Barumun yang mengalir melintasi Kabupaten Labuhan Batu Selatan. Sungai Nahula adalah sungai terletak di Desa Binanga Dua Kecamatan Silangkitang. Diketahui pada Sungai Nahula tingkat keanekaragaman jenis ikannya cukup tinggi. Berbagai ikan dapat dijumpai di sungai ini, salah satunya adalah ikan mirik (Mastacembelus spp).

Masyarakat Desa Binanga Dua biasa menyebutnya ikan mirik. Ikan mirik biasa juga disebut ikan sili, mempunyai keanekaragaman jenis yang yang cukup tinggi. [1]; [2] diketahui famili Mastacembelidae memiliki 3 genus yakni: Mastacembelus (61 spesies), Macrognathus (24 spesies), dan Sinobdella (1 spesies).

Ikan mirik merupakan ikan yang dikonsumsi oleh masyarakat, namun di beberapa daerah di Indonesia sudah lama dijadikan sebagai ikan hias.[3] ikan mirik merupakan ikan ekonomis penting yang dimanfaatkan sebagai ikan konsumsi dan juga ikan hias. Masyarakat menjadikannya sebagai ikan hias karena mempunyai bentuk dan pola warna yang menarik.

[2] ikan mirik salah satu jenis ikan air tawar dari Famili Mastacembelidae yang saat ini sudah sulit ditemukan di alam. Sebagian besar masyarakat melakukan aktivitas penangkapan ikan di sungai untuk dikonsumsi maupun diperdagangkan. Penangkapan ikan Sili yang berlangsung sepanjang tahun merupakan potensi ancaman bagi kelestarian ikan tersebut.[4]. 


\section{$\mathcal{H a l}: 8-12$}

Mengingat kondisi populasi ikan mirik yang sudah mulai sulit dijumpai di alam serta penyebarannya hanya dijumpai pada beberapa sungai tertentu saja, maka perlu dilakukan penelitian untuk mengetahui status bioekologi ikan ini di Indonesia khususnya di Pulau Sumatera. Penelitian terkait studi biodiversitas ikan mirik di Sungai Nahula Labuhan Batu Selatan belum ada yang melakukan. Data hasil penelitian nantinya sangat dibutuhkan sebagai sumber informasi tentang kondisi keanekaragaman ikan mirik di Sungai Nahula. Mengingat penelitian tentang ikan mirik masih sedikit di Indonesia dan terkhususnya di wilayah Sumatera Utara.

\section{Bahan dan Metode}

\subsection{Waktu dan Tempat}

Penelitian ini dilaksanakan pada bulan Januari sampai dengan Maret 2019 di Sungai Nahula yang terletak di Desa Binanga Dua, Kecamatan Silangkitang, Kabuapaten Labuhan Batu Selatan, Provinsi Sumatera Utara.

\subsection{Bahan}

Bahan yang digunakan pada penelitian ini adalah :

1. Ikan Mirik sebagai objek penelitian

2. Air sungai sebagai sampel pengamatan parameter kualitas air.

\subsection{Alat}

Alat yang digunakan pada penelitian ini adalah :

1. $\mathrm{pH}$ meter untuk mengukur $\mathrm{pH}$ air

2. DO meter untuk mengukur kelarutan oksigen perairan

3. Sechi disk untuk mengukur tingkat kecerahan air

4. Pelampung, bandul, tali pancing, dan stopwatch untuk mengukur kecepatan arus

5. Rol untuk mengukur panjang ikan

6. Timbangan analitik untuk mengukur bobot ikan

7. Pancing, Jala, dan elektrik fish untuk menangkap ikan

8. GPS (Global Positioning System) untuk menentukan titik stasiun pengamatan

\subsection{Jenis Penelitian}

Penelitian ini merupakan penelitian eksploratif. Penelitian eksploratif adalah penelitian yang dilakukan untuk mencari sebab atau hal-hal yang mempengaruhi terjadinya sesuatu dan dipakai manakala kita belum mengetahui secara persis dan spesifik mengenai objek penelitian [5].

\subsection{Metode Penentuan Stasiun Pengamatan}

Metode penentuan titik stasiun pengamatan sebagai lokasi pengambilan sampling ikan menggunakan metode purposive sampling. Menurut [5] pengertian purposive sampling adalah teknik penentuan sampel dengan berdasarkan kriteria-kriteria atau pertimbangan tertentu. Pada penelitian ini pertimbangannya yakni berdasarkan tingkat kedalaman air sungai berbeda. Hal ini dengan harapan jenis dan ukuran ikan mirik yang tertangkap tentunya akan berbeda pula.

\subsection{Prosedur Penelitian}

\subsubsection{Penentuan Stasiun Pengamatan}

Adapun rencana penentuan lokasi stasiun pengamatan adalah berdasarkan kedalaman air sungai, yakni sebagai berikut:

1. Stasiun 1 (Kedalaman Sungai \pm 1 meter)

2. Stasiun 2 (Kedalaman Sungai $\pm 1,5$ meter)

3. Stasiun 3 (Kedalaman Sungai \pm 2 meter) 


\section{$\mathcal{H a l}: 8-12$}

Selanjutnya adalah menetapkan titik stasiun pengamatan, dengan melakukan pengambilan titik koordinat. Pengambilan titik koodinat menggunakan Global Positioning System (GPS). Titik koodinat kemudian dicatat dan kemudian dilakukan pembuatan peta lokasi penelitian.

\subsubsection{Pengambilan Sampel}

Pada penelitian untuk penangkapan ikan sampel dilakukan dengan menggunakan alat tangkap berupa pancing dan elektrical fishing (stroom). Pengambilan sampel ikan dilakukan selama 3 bulan berturut-turut, dimana pengambilan dilakukan sebanyak 1 kali pada setiap bulannya.

\subsubsection{Analisis Data}

Data yang dianalisis pada penelitian ini adalah Indek Keanekaramanan, Indeks Kesreagaman dan Indek Similaritas menggunakan formula [6]. Selanjutnya Indeks Dominansi menggunakan formula [7]. Analisis data menggunakan aplikasi program Microsoft Excel.

\section{Hasil dan Pembahasan}

\subsection{Indek Keanekaragaman}

Keanekaragaman ikan menggambarkan adanya kekayaan ikan di suatu kawasan tersebut. Indeks Keanekaragaman ( $\left.\mathrm{H}^{\prime}\right)$ ikan mirik berdasarkan hasil analisis data maka dipeoleh pada Stasiun 1 adalah 0 , Stasiun 2 adalah 0,15, dan Stasiun 3 adalah 0 . Selanjutnya data dapat dilihat pada tabel 1. di bawah ini:

Tabel 1. Indeks Keanekaragaman Ikan Mirik Di Sungai Nahula.

\begin{tabular}{clcc}
\hline No & Lokasi & Indeks Keanekaragaman & Kategori \\
\hline 1 & Stasiun 1 & 0 & Rendah \\
2 & Stasiun 2 & 0,15 & Rendah \\
3 & Stasiun 3 & 0 & Rendah \\
\hline
\end{tabular}

Indeks Keanekaragaman $\left(\mathrm{H}^{\prime}\right)$ pada semua stasiun dikategorikan rendah, hal ini diduga karena Sungai Nahula merupakan sungai yang tidak lebar dan tidak dalam. [8] menyatakan bahwa indeks keanekaragaman ikan yang tinggi pada sungai berhubungan dengan luas dan kedalaman sungai. Adanya hubungan positif antara kekayaan jenis dengan suatu area yang ditempati berhubungan pula dengan keanekaragaman jenis ikan lainnya.

\subsection{Indeks Keseragaman}

Hasil analisis Indeks Keseragaman $(\mathrm{J})$ ikan mirik di Sungai Nahula maka diperoleh nilai pada Stasiun 1 adalah 0 , Stasiun 2 adalah 0,22, dan Stasiun 3 adalah 0 . Data selengkapnya dapat dilihat pada tabel 2.di bawah ini:

Tabel 2. Indeks Keseragaman Ikan Mirik Di Sungai Nahula

\begin{tabular}{cccc}
\hline No & Lokasi & Indeks Keseragaman & Kategori \\
\hline 1 & Stasiun 1 & 0 & Keseragaman Populasi Rendah \\
2 & Stasiun 2 & 0,22 & Keseragaman Populasi Rendah \\
3 & Stasiun 3 & 0 & Keseragaman Populasi Rendah
\end{tabular}

Indeks Keseragaman pada semua stasiun pengamatan menunjukan kategori keseragaman populasi rendah, hal ini diduga karena Sungai Nahula dijadikan tempat penambangan pasir dan batu kali menjadikan kondisi air sungai menjadi keruh. Menurut [2] penambangan pasir dapat menyebabkan perubahan habitat secara drastis dan tentunya dapat mengganggu kondisi alamiah habitat ikan di sungai. 


\section{$\mathcal{H a l}: 8-12$}

Selanjutnya hasil penelitian [9] diperoleh nilai 0,25-0,48, hal ini menunjukan keseragaman populasi rendah dan komunitas tertekan. Berbeda dengan hasil yang didapatkan [10] yakni nilai Indeks Keseragaman berkisar antara 0,60-0,82 atau mendekati 1 yang menandakan kemerataan bobot antar spesies relatif sama atau jumlah individu pada masing-masing spesies relatif sama, sehingga sebaran jumlah maupun bobot individu ikan relatif merata.

\subsection{Indeks Similaritas}

Hasil analisis nilai Indeks Similaritas dapat dilihat pada tabel 3. berikut ini:

Tabel 3. Indeks Similaritas Ikan Mirik Di Sungai Nahula

\begin{tabular}{cccc}
\hline No & Lokasi & Indeks Similaritas & Kategori \\
\hline 1 & Stasiun 1 dan 2 & $66 \%$ & Mirip \\
2 & Stasiun 2 dan 3 & $66 \%$ & Mirip \\
3 & Stasiun 3 dan 1 & $100 \%$ & Sangat mirip \\
\hline
\end{tabular}

Pada stasiun 1 dan 2 serta stasiun 2 dan 3 memiliki indeks similaritas yang sama (66\%) dengan kategori mirip, sedangkan pada stasiun 3 dan 1 memiliki nilai indeks similaritas (100\%) dengan kategori sangat mirip. Hasil penelitian ini menunjukan terdapat perbedaan komposisi jenis ikan pada 3 stasiun pengamatan di Sungai Nahula. Diduga perbedaan ini dikarenakan vegetasi antar setiap stasiun yang beragam sehingga mempengaruhi perjumpaan jenis-jenis ikan. Menurut pendapat [11] jenis vegetasi yang beragam pada suatu habitat memiliki potensi ketersedian pakan yang lebih baik dibandingkan habitat lain dengan vegetasi yang kurang beragam. Selain perbedaan vegetasi, letak habitat yang berjauhan dapat menyebabkan ikan tidak memiliki daya jelajah.

\subsection{Indeks Dominansi}

Berdasarkan hasil analisis Indeks Dominansi $(C)$ pada masing -masing stasiun pengamatan dapat dilihat pada tabel 4. berikut ini:

Tabel 4. Indeks Dominansi Ikan Mirik Di Sungai Nahula

\begin{tabular}{clc}
\hline No. & Lokasi & Indeks Dominansi (C) \\
\hline 1 & Stasiun 1 & 0,16 \\
2 & Stasiun 2 & 0,08 \\
3 & Stasiun 3 & 0,02 \\
\hline
\end{tabular}

Pada tabel di atas Indeks Dominansi pada stasiun $1(0,16)$ stasiun $2(0,08$, dan stasiun $3(0,02)$. Nilai indeks dominansi tersebut menandakan tidak terjadi dominasi suatu spesies terhadap spesies yang lain di dalam komunitas sehingga struktur komunitas dalam keadaan stabil. Berdasarkan hasil penelitian [10] di Sungai Gendol dan Sungai Opak, menjelaskan komunitas ikan berada dalam kondisi sedang dan tertekan ringan. Dominansi jenis pada suatu perairan sering terjadi karena beberapa hal antara lain kompetisi pakan alami oleh jenis tertentu, perubahan kualitas lingkungan, dan tidak seimbangnya antara predator dan mangsa sehingga terjadi kompetisi antar jenis [12]..

\section{Kesimpulan}

Kesimpulan yang diperoleh berdasarkan hasil analisis data penelitaian adalah Indeks Kenaekaraman ikan mirik di Sungai Nahula dikategorikan rendah; Indeks Keseragaman dikategorikan keseragaman populasi rendah; Indeks Similaritas pada stasiun 1 dan 2 dan stasiun 2 dan 3 dikategorikan mirip, sedangkan pada stasiun 3 dan 1 dikategorikan sangat mirip; dan Indeks Dominansi berdasarkan hasil analisis dikatergorikan tidak ada spesies yang mendoninasi.

\section{Ucapan Terima Kasih}


$\mathcal{H a l}: 8-12$

Pada kesempatan ini penulis mengucapkan rasa terima kasih yang sebesar-besarnya kepada Bapak Khairul, S.Pi, M.Si selaku dosen pembimbing 1 dan lbu Rosmidah Hasibuan, S.Pd, M.Si selaku dosen Pembimbing 2, serta seluruh teman-teman seperjuangan terutama kelompok sains (Sains Community 2018) atas semua bantuan dan arahannya. .

\section{Daftar Pustaka}

[1] Cakmak, E. \& Alp, E. Morphological Differences Among The Mesopotamian Spiny Eel, Mastacembelus mastacembelus (Bank \& Solander 1794) Populations. Turkish Journal of Fisheries and Aquatic Sciences, 10: 87-92, 2009..

[2] Yunus, A., Miswar Budi Mulya, Dan Irwanmay. Kajian Morfologis Dan Kelimpahan Ikan Sili (Famili : Mastacembelidae) Di Sungai Seruai Desa Namu Suro Kabupaten Deli Serdang Provinsi Sumatera Utara. Jurnal Aquacoastmarine, 15 (1) : 1 - 13, 2016.

[3] Ario, A. 2010. Mengenal Satwa Taman Nasional Gunung Gede Pangrango. Conservation International (IC), Jakarta.

[4] Handayani, B.K.T., Sofia Ery Rahayu, dan Dwi Listryorini. Identifikasi Ikan Sili Berdasarkan Karakteristik Morfologi dan DNA Barcode Cytochrom-Coxydase Sub Unit I. Diakses tanggal 2 Februari 2019 pada laman: http://jurnalonline.um.ac.id/data/artikel/artikel05956048BF4358E0DAFE5A83BA1909DF.pdf., 2014.

[5] Sugiyono. 2013. Metode Penelitian Kuantitatif dan Kualitatif $R$ \& D. Alfabeta, Bandung.

[6] Krebs, C.J. 1978. Ecological Methodology. New York: Harper and Row Publisher.

[7] Odum, E. P., (1993). Dasar-Dasar Ekologi Edisi Ketiga. T Samingan (Penerjemah). Gadjah Mada University Press, Yogyakarta.

[8] Atifah. Y, dan Fitri, A.L. Keanekaragaman Jenis Ikan Di Sungai Batang Gadis Mandailing Natal Sumatera Utara. Scripta Biologica. 4(4): 215-219, 2017.

[9] Samitra, Dian dan Zico Fakhrur Rozi. Keanekaragaman Ikan Di Sungai Kelingi Kota Lubuklinggau. Jurnal Biota Vol. 4 No. 1: 1 - 6, 2018.

[10] Djumanto dan Probosunu. Biodiversitas Sumber Daya Ikan di Hulu Sungai Opak.Jurnal Ikhtiologi Indonesia, 11 (1):1-10, 2011

[11] Nurudin, Febrian Achmad. 2013. Keanekaragaman Jenis Ikan di Sungai Sekonyer Taman Nasional Tanjung Puting Kalimantan Tengah. Skripsi Jurusan Biologi Fakultas Matematika Dan IImu Pengetahuan Alam Universitas Negeri Semarang, Semarang.

[12] Maturbongs, R.M., Sisca Elviana, Sunarni Sunarni, dan Dominggus deFretes. Studi keanekaragaman ikan gelodok (Famili: Gobiidae) pada muara Sungai Maro dan Kawasan Mangrove Pantai Kembapi, Merauke. Depik, Volume 7, Number 2 : 177-186, 2018 